\title{
The Legal Protection of Teacher Professionalism
}

\author{
Harpani Matnuh \\ Civics Education Study Program \\ Lambung Mangkurat University \\ Banjarmasin, Indonesia \\ harpani.matnuh@yahoo.com
}

\begin{abstract}
Teachers are professional educators with the primary task of educating, teaching, guiding, directing, training, assessing, and evaluating early childhood education on formal education, primary education, and secondary education. As the professionals in the field of education, teachers have a great task and responsibility in achieving the goals of national education. In order to uphold discipline and maintain school as well as orders in teaching and learning processes, teachers have the right to sanction their students who violate religious norms, morality norms, decency norms, written and unwritten rules set by teachers, educational unit level regulations and regulations legislation under the authority. The Act No.14 Year 2005 on Teachers and Lecturers as well as Government Regulation No.74 Year 2008 on Teachers firmly mention that teachers who have the certificate of educators are entitled to basic salary, allowances attached to salary, additional income professional allowance, functional allowance, special allowances, and additional benefits related to their duties as teachers who are set by the principle of the award on the basis of achievement and legal standards in carrying out their profession. Objective conditions that occur are teachers are exposed to violence, threats, discriminatory treatment, intimidation, and unfair treatment by the students, students' parents, society, bureaucracy, or other parties.
\end{abstract}

\section{Keywords-legal protection; teacher professionalism}

\section{INTRODUCTION}

Legal protection toward teacher profession is intended to provide a guarantee of freedom and security for teachers in carrying out their professional duties as stated in Article 1 (1) of Law Number 14 of 2005 that; teachers are professional educators with the main task of educating, teaching, guiding, directing, training, assessing, and evaluating students in early childhood education through formal education, basic education, and secondary education. PP No.41 of 2009 confirms that; Teachers who have an educator certificate are given a professional allowance of one principal salary which is attached to the salary as a reward for their professionalism. Furthermore, the teachers in carrying out their duties as educators have the freedom to give sanctions to their students who violate religious norms, compulsory norms, courtesy norms, written or unwritten regulations set by the teachers, education unit level regulations, and legislation in the learning process that is located under its authority $[1,2]$

The legal protection referred to in Article 41 (1) PP No.74 of 2008 is; The teachers have the right to get legal protection from acts of violence, threats, discriminatory treatment, intimidation, or unfair treatment from the students, parents of students, the community, the bureaucracy, or other parties [3].

Teachers as professionals in the field of Education have been given basic rights (human rights) that must be respected, upheld by the state, government, law and every person for the honor and protection of the dignity of teachers.

Based on the research method used in this study that is normative research (legal research), the objectives to be achieved are; "What are the rights of teachers and what is the legal protection of the rights of teachers as professionals in the field of education?".

Teachers in carrying out their professional duties, besides being faced with the obligation to develop their professionalism, achieving national education goals that are increasingly qualified and competitive, are also faced with increasingly complex challenges and disruptions related to human rights, legal violations, geographical location, school environment, and welfare teacher. Teachers often get threats, acts of violence, lawsuits from students and parents, as well as unfair treatment from the law such as providing professional allowances.

Problems or constraints faced by teachers in implementing and developing their professional duties are rooted in the lack of legal certainty and/or legal protection given to teachers as professional staff in the field of education.

\section{METHOD}

This research is a normative legal research that is conducting a research by reviewing and analyzing various laws and regulations, legal principles, legal systematics, vertical and horizontal legal synchronization relating to legal protection of the rights of teachers as professionals in the field of education. The employed approaches were the statute approach and conceptual approach.

In addition, literature research (library research) was also used which functions to complement and support the discussion of the material sources of legislation that have been obtained. This is to meet the need for a more detailed explanation of the issue of law in books with the law in action. 


\section{DISCUSSION}

\section{A. Welfare State Theory}

In welfare state theory, the state is placed as the center for the realization of legal certainty and welfare in every aspect the people's lives fairly and equitably.

State welfare basically emerged in order to uphold the existence of law state system that ensures law certainty and protection to human rights, and also as antithetical to the types of state law and legal functions as the "night watch" or "nachwechterstaat".

When there is a legal obscurity that creates multiple interpretations of the applicable law, the interpretation of the law should not be contradicted by legal principles and legal functions. Law occupies the highest position, everyone is obliged to obey the law and uphold the law without exception. Everyone can only be punished if he/she violates the law. On the other hand, the law cannot force anyone to do something impossible or unreasonable (Lex niminem cogit ed impossibelia).

Moreover, 1. W. Ridwan Tjandra stated that: the welfare state theory provides the authority principle to the state to play an active role in the public activities, to protect the weaker groups in the society (the lower class), thus the state must actively regulate and distribute the authorization of resources for welfare [4].

Welfare State Theory to Indonesia has been written in the Preamble of NKRI UUD 1945, the fourth paragraph that stated that:" kemudian dari pada itu untuk membentuk suatu Pemerintahan Negara Indonesia yang melindungi segenap bangsa Indonesia dan seluruh tumpah darah Indonesia dan untuk memajukan kesejahteraan umum....". Based on the meaning of the contents of the Preamble of UUD 1945, it is instructed that the state and government are obliged to provide protection and service to the public interest, in order to objectify the commonweal in every aspect of the people' live.

\section{B. Teacher Professionalism Legal Protection}

Article 1 (1) of Law Number 14 Year 2005 affirms that teacher is a professional educator with the main task of educating, teaching, guiding, directing, training, assessing and evaluating learners in formal early childhood education, primary education and secondary education [1].

In order to provide discretion for the teacher in carrying out their main duties as a professional educator, the teacher is given the right to impose sanctions on students who violate the norm or interfere with the learning process as stated in Article 39 of Government Regulation Number 74 Year 2008 [3]:

- Teacher has the freedom to impose sanctions on their students who violate religious norms, morality norms, decency norms, the written or unwritten rules set by the teacher, education unit level regulations, and laws in the learning process that are under the jurisdiction.

- Sanctions, as referred in paragraph (1), may be in form of a reprimand and/ or warning, both oral and written, and educational punishments in accordance with the education principle, teacher's code of ethics, and laws.

- In the violation of the educational unit rules committed by learners which granting sanctions is beyond the authority of the teacher, the teacher should report to the educational unit leader.

- In the violation of law committed by the learner, the teacher should report to the leader of the education unit to be followed up in accordance with the provisions of law.

Minister of Education and Culture, Muhajir Effendy said that "physical sanctions can be tolerated to some extent". Is the physical sanction that is stated a sanction that in accordance with the limits of dignity based on the development of the student such as; push-ups, running around the field, cleaning the environment, cutting hair, writing or making a writing etc.

The year 2005 is a new milestone of government appreciation for the teacher as professional by guaranteeing the rights that given to the teacher as in Article 14 (1) of Law No.14 Year 2005 which provides welfare guarantee that should be accepted by the teacher. The teacher has the right to [1]:

- earn income above the minimum living and professional welfare;

- obtain promotions and awards based on work performance;

- obtain protection in the performing duties and the rights of intellectual and wealth;

- obtain opportunities to improve competence;

- obtain and utilize learning facilities and infrastructure to support professional duties;

- have the freedom to judge and contribute to determine of graduation, awards, and/ or sanctions to learners in accordance with the educational principle, teacher's code of ethics, and laws;

- obtain security and safety in carrying out the duties;

- have the freedom to associate within professional organizations;

- have the opportunity to play a role in the determination of education policy;

- obtain opportunities to develop and enhance academic qualifications and competency; and/or;

- obtain training and professional development in the field.

\section{Teacher Professional Allowance}

The teacher professional allowance is given to teacher and lecturer who have educator certificates in recognition to their professionalism based on provisions regulated in Article 15 Government Regulation Number 41 Year 2009 (1) that teacher [2]: 
- has one or more Educator Certificates that have been assigned a registry number by the Department;

- fulfill workload as a teacher;

- teach as a subject teacher and/ or a classroom teacher in an educational unit in accordance with the designation of his/her Educator Certificate;

- enroll in the Department as a Permanent Teacher;

- has an age maximum of 60 (sixty) years; and

- does not tie up as a permanent employee to other institution other than the designated education unit.

Provision of professional allowance for teacher and lecturer shall be stopped if the teacher or lecturer no longer fulfills the requirements as stipulated by the applicable legislation.

Associated with the deduction of teacher certification allowance that does not meet the 24 hours/week teaching hours either because of sick or permit to worship is contradicted to the principle of law and does not have a strong juridical foundation.

Government Regulation Number 11 Year 2017 on leave for civil servant's states that every civil servant has the right to obtain leave that consists of; annual leave (not applicable to teachers and lecturers), paid leave, sick leave, maternity leave, leave for important reasons, mass leave and leave out of the state responsibility. Taking a leave to perform worship such as Umroh or pilgrimage is included into leave for important reasons [5].

Permission to perform worship according to Ps.30 (2.e) Law Number 13 Year 2003 on Employment confirms that; companies are obligated to pay wages if employees/ laborers cannot work because of taking a leave/ leave to worship [6].

\section{Justification and Forgiving Reasons}

In the provisions of criminal law, the reasons that can abolish criminal or unaccountable reasons for a person (defendant) because it comes from outside of the person (uitwendig) are [7]:

- Article 48 of the Criminal Code; the existence of force (overmacht)

- Article 249 of the Criminal Code; forced defense (noodweer)

- Article 50 of the Criminal Code; implementing the law

- Article 51 of the Criminal Code; carrying out office order

From the description above, there are 3 reasons that can abolish the legal process of a person (defendant) who violates the law. They are:

1) Justification Reason: The justification reason is the existence of something that can be used as the reason or background of the actions that has been done by a person (defendant) who is deemed to have committed a criminal offense but such act can be legally recognized as a proper and right action. A justified reason, for example, is when a person commits an act because of carrying out a law order in accordance with the functions and authorities possessed by a person or institution provided by the state or law.

2) Forgiving Reason: The forgiving reason is a reason that can be used as a basis to remove (forgive) the defendant's wrongdoing which has committed the act against the law because the defendant is considered innocent. The reason that can be used as a basis for forgiveness is the form of the act committed by the defendant such as forced action or an act beyond the conscious limit.

3) Reason for Removing Prosecution: The reason for removing the prosecution is not due to justification or forgiveness but the government, for the sake of public interest and/or benefit, does not undertake or remove prosecution.

R. Soesilo said that; the offense consists of Legal Offense (rechtsdelict) which is an act that is contradicted with the positive legal principles which everyone will declare as a crime act. Law Offense (wetsdelict) is a small criminal act such as unlicensed cockfighting [8].

Based on the above description, the teacher's action in punishing the students physically in the form of a light punishment can be analogized as a law offense or a minor crime that can be forgiven or justified so that it should be the reason for the prosecution elimination. This is in line with Article 5 (1) of Law Number 48 Year 2009 concerning the Authority of the Judiciary which states that; Judges and Constitutional judges are required to explore, to follow, and to understand the legal values and sense of justice living in the society [9]

\section{CONCLUSION}

- Constitutionally teachers have been declared as professionals in the field of education and have the right to get legal protection from acts of violence, threats, discriminatory treatment, intimidation, or unfair treatment from students, parents of students, the community, the bureaucracy, or other parties;

- Teachers who already have a certificate of educators are entitled to receive a professional allowance of one salary which is attached to the salary as a reward for their profession;

- Teachers have the freedom to impose sanctions on their students who violate religious norms, misconduct norms, politeness norms, written or unwritten regulations set by the teacher, education unit level regulations, and legislation in the learning process which is under his authority.

- Teachers who cannot teach or have fewer hours of faceto-face teaching due to illness or perform worship (Umrah or Hajj) cannot be punished (deducted from the certification fee) because it is not a legal act, sick permission and worship has been constitutionally guaranteed; 
- Teachers who punish students cannot be investigated by the police before being examined by the Honorary Council of the teacher's code of ethics.

\section{REFERENCES}

[1] Undang-Undang Nomor 14 Tahun 2005, tentang; Guru dan Dosen.

[2] Peraturan Pemerintah Nomor 41 Tahun 2009 tentang Tunjangan Profesi Guru dan Dosen.
[3] Peraturan Pemerintah Nomor 74 Tahun 2008, tentang Guru.

[4] W. Ridwan Tjandra. Dinamika Peran Pemerintah dalam Perspektif Hukum Administrasi. Yogyakarta : Atma Jaya University, 2004.

[5] Peraturan Pemerintah Nomor 11 Tahun 2017 tentang Cuti PNS.

[6] Undang-Undang Nomor 13 Tahun 2003 tentang Ketenagakerjaan

[7] Kitab Undang-Undang Hukum Acara Pidana.

[8] R. Soesilo, Pokok-Pokok Peraturan Umum dan Delik-Delik Khusus, Bogor: Politeia, 2014.

[9] Pasal 5 (1) Undang-Undang Nomor 48 Tahun 2009 tentang Otoritas Kehakiman 